International Review of Social History 45 (2000), pp. 179-196

(C) 2000 Internationaal Instituut voor Sociale Geschiedenis

\title{
Stepping on Two Boats: Urban Strategies of Chinese Peasants and Their Children*
}

\author{
DANYU WANG
}

\section{INTRODUCTION}

During the 1990s, over seventy per cent of the married men and adult children of Stone Mill village in northeastern China have been employed in wage labor each year.' Because a vast number of household laborers (i.e. husbands, sons, and daughters) have nonagricultural jobs outside the village, daily agricultural tasks are performed by married women and elderly men, who are fondly described by the villagers of Stone Mill as "Troop Number $3860^{\prime \prime}$ ( 3860 budui). The number 38 refers to International Women's Day, March 8, representing the women in the village's agricultural labor force, while the number 60 represents the minimum age of the elderly agricultural workers.

Since the 1980s, Chinese peasants, like those in Stone Mill, have sought to improve their income by working in nonagricultural areas, such as local village-township enterprises and family businesses, or by migrating to cities to seek urban employment. Local nonagricultural employment has been incorporated into rural household economies. ${ }^{2}$ With new job opportunities created by the rapid economic development in cities, massive urban migration by the rural population has been taking place. In the 1990s, not including migration within each county, fifteen to twenty-five per cent of

\footnotetext{
* I would like to thank Joseph Adams and Dona Geyer for their editorial assistance and comments on this paper. I wish to thank the Wenner-Gren Foundation (Grant 6234, 1997), and the Population Studies and Training Center at Brown University for providing funding for my field research.

I. The name of the village and names of the villagers appearing in this paper are all pseudonyms. Unless otherwise noted, the demographic data about Stone Mill is from my 1997 survey of 315 Stone Mill couples, with wives born after 1930.

2. For local or family level studies of peasants' employment in village-township enterprises or private businesses, see Elisabeth Croll, "The New Peasant Economy in China", in A.H. Stephan Feuchtwang and Thierry Pairault (eds), Transforming China's Economy in the Eighties I: The Rural Sector, Welfare, and Employment (London, 1988), pp. 77-100; Samuel P.S. Ho, Rural China in Transition: Non-Agricultural Development in Rural Jiangsu, 1978-1990 (Oxford, 1994); Graham E. Johnson, "Family Strategies and Economic Transformation in Rural China: Some Evidence from the Pearl River Delta", in Deborah Davis and Stevan Harrell (eds), Chinese Families in the PostMao Era (Berkeley, CA, 1993), pp. 103-138; Victor Nee et al., "Peasant Entrepreneurs in China's 'Second Economy': An Institutional Analysis', Economic Development and Social Change, 39 (1991), pp. 293-310; Edward B. Veemer, "Experiment with Rural Industrial Shareholding Cooperatives: The Case of Zhoucun District, Shandong Province", Chind Quarterly, 314 (1995), pp. 75-107.
} 
rural laborers nationwide migrated to cities for six months or longer; notably, fifty per cent of them were people below the age of twenty-three. ${ }^{3}$ Nonagricultural employment and nonhousehold-organized economic activities (such as working for local enterprises) have become a substantial component of the peasant household economy. At a national level, the proportion of nonagricultural income in the total income of rural households has increased from ten per cent in 1980 to twenty-five per cent in 1985 and then to thirty-five per cent in $1995 .{ }^{4}$

The extent to which peasant households profit from employment in local village-township enterprises and family businesses or from migration to cities varies in each locality and each household depending on the availability of local employment and on migratory network connections. The case of Stone Mill, examined in this paper, illustrates a community of peasant households in which many work at wage labor jobs. "Stepping on two boats" is a Chinese saying that describes people who commit to two jobs in order to secure their social and economic advancement. Although the expression has a somewhat negative connotation, there is nothing negative implied about the modern Chinese peasant's strategy of combining farming and wage labor. Diversifying household economy by combining farming and wage labor is a vital household strategy that has helped the impoverished Chinese peasants to survive in the rapid economic development of postsocialist China.

Diversifying household economies was a typical survival strategy of traditional Chinese households before the socialist reforms in the 1950s. However, the way peasants diversified their sources of income in the 1980s-1990s changed in response to the new predicaments facing them in the postsocialist state. The goals of each family have remained the same, namely to ensure a subsistence standard of living and to maintain the continuity and prosperity of the family, but the means of achieving these goals are different. As will be shown here, the traditional survival strategy of expanding family farmland has been replaced by that of improving income, since private ownership of farmland is not an option in the postsocialist state and wage labor employment is available. In addition, the socioeconomic disadvantages created by the socialist state since the I950s have continued to cloud the lives of Chinese peasants in the new era of market development and globalization of the 1980s-1990s. This paper argues that, for the younger generation, acquiring nonagricultural jobs has become crucial to avoiding the fate of peasant life and escaping rural poverty. No doubt, a collective effort by both

3. See Yaer Zhuang (ed.), Zhongguo Renkou Qianyi Shuju Ji [Migration Data of China] (Beijing, 1995), p. 238.

4. See Huanyan He et al. (eds), Zhongguo Nongcun Zhuhu Diaocha Nianjian [Chinese Rural Household Survey Annals] (Beijing, 1993), p. 9; idem, Zhongguo Nongcun Tongji Nianjian, I9g2 [Chinese Rural Statistical Annals, rg92] (Beijing, 1992), p. 216; Xinmin Zhang et al. (eds), Zhongguo Nongcun Tongji Nianjian I996 [Chinese Rural Statistical Annals, 1996] (Beijing, 1996), p. 280. 
parents and children to ensure the survival of the family as a whole has compromised the interests of some (i.e. parents) and benefited others (i.e. children). This has thus brought about changes in gender and generational relationships within the household.

In the following sections, this paper first examines the predicament of household agricultural production in the postsocialist state. It will then proceed to investigate the economic strategies used by many peasant households, which can be described, in short, as maintaining agricultural production and prioritizing adult children's urban employment, while maximizing the household's wage labor income. Lastly, this paper will probe the impact of these economic strategies on peasant households with respect to the division of labor, financial management, and generational independence.

\section{THE PREDICAMENT OF AGRICULTURAL PRODUCTION AND RURAL POVERTY}

The many facets of socioeconomic change in China have exerted a great deal of pressure on peasant households. Three factors are particularly pertinent to the "two-boats effect" in the peasant population. The first is a surplus of agricultural labor. The national population of half a billion in the 1950 s has now more than doubled to 1.3 billion at the start of the twenty-first century. The average amount of farmland per rural inhabitant nationwide is two $m u$, which equals 1,334 square meters, while in the highly populated areas of the east and southeast, this average is much lower. ${ }^{6}$ The second factor is the state's socioeconomic policies centering on urban-industrial development, which provided strong state protection and support of industrial production, urban consumption, and urban social welfare. These policies have been the structural basis for urban-rural inequality and rural poverty since the 1950 s. $^{7}$ A set of dichotomies such as "urban versus rural resident" (cheng shi ren vs. nongcun ren) and "nonagricultural versus agricultural employment" (fei nongye

5. One $m u$ is equal to 667 square meters or 0.165 acre.

6. See He et al., Chinese Rural Statistical Annal, 1992, p. 215; Zhang et al., Chinese Rural Statistical Annals, rg96, p. 58.

7. For urban-rural inequality in China's postsocialist economy, see Marc Blecher, "Balance and Cleavage in Urban-Rural Relations", in William L. Parish (ed.), Chinese Rural Development: The Great Transformation (Armonk, NJ, 1985), pp. 219-245; Philip C.C. Huang, The Peasant Family and Rural Development in the Yangzi Delta, 1350-1988 (Stanford, CA, 1990), pp. 288-301; Sulamith Heins Potter et al., China's Peasants: The Anthropology of a Revolution (Cambridge, 1990); Jonathon Unger, "The Class System in Rural China: A Case Study”, in James. L. Watson (ed.), Class and Social Stratification in Post Revolutionary China (New York [etc.], 1984), pp. 121-I4I; Andrew G. Walder, "Social Change in Post-Revolution China", Annual Review of Sociology, I5 (1989), pp. 405-424; Martin K. Whyte, "City Versus Countryside in China's Development", Problems of Post-Communism, 43 (1996), pp. 9-22; David Zweig, Freeing China's Farmers: Rural Restructuring in the Reform Era (Armonk, NJ, 1997). 
gongzuo vs. wunong) has separated urban and rural society in the socioeconomic hierarchy. The third factor is the development of the market economy on the national level in which peasants have been forced to compete. On the one hand, the rising prices of agricultural production materials have been increasing the cost of agricultural production, while on the other hand, the prices of agricultural products have been dropping throughout the 1990s, because of the limited size of the urban market. High production costs and low sales prices have resulted in little or no profit for many peasant households. These three factors have greatly contributed to rural poverty, as has the substantial economic discrepancies between rural and urban populations in the past five decades. The per capita income gap between urban and rural inhabitants has been as high as 2.5:1. ${ }^{8}$

The villagers of Stone Mill, most of whom earned an annual income equal to the national rural average of 1,600 yuan (i.e. US $\$ 200$ ) per person in the mid-1990s, exemplify the average Chinese peasant's struggle to survive agricultural impoverishment in China. The village is located on the Liaodong peninsula in the northeast, one of the most industrialized and urbanized areas in China. It is ten kilometers away from the county seat, which is a twentyminute trip by bus or an hour by bicycle. A railway and a recently constructed highway also provide villagers easy accesses to Dalian City, the largest urban center of Liaodong peninsula, as well as to other cities in the northeast region. Easy access to cities has allowed Stone Mill villagers to migrate to a city temporarily or commute to the local town on a daily basis. After the implementation of the household farming policy in 1982, the local government allocated to eligible individuals equal shares of grain fields (kouliang tian), vegetable gardens (caiyuanzi), and apple trees as measured by unit production. Households in Stone Mill received vegetable plots of about o.I $m u$ per person, farmland ranging from less than $0.1 m u$ to slightly over one $m u$ per person, and twenty to forty apple trees per person depending upon the productivity of the trees. Villagers were given the right to farm this land and decide on their own household production, however they were granted neither ownership of the land nor the right to sell or buy land.

The agricultural economy of Stone Mill today combines subsistence and cash economies (i.e. farming and fruit production). The cornfield, vegetable garden, and domestic farm animals supply the household's basic consumption of grain, vegetables, meat, and cooking oil. These subsistence productions of grain and vegetables, which provide a baseline of survival for rural households in China's rapid economic development, are protected by the state through the household farming policy. Fruit production and wage labor, which enable each household to obtain cash income beyond a mere subsistence level, are

8. Charles Goddard, China Market Atlas, Research Report (Hong Kong, 1997), p. 193; Whyte, "Cities Versus Countryside". 
Table $\mathrm{I}$. Prices of apples in comparison with prices of rice (yuan/jin I jin $=0.5$ $\mathrm{kg})$

\begin{tabular}{lcccl}
\hline & Before 1975 & $1975-1983$ & 1988 & 1996 \\
\hline Apples & 0.185 & 0.23 & 1.10 & 0.5 \\
Rice & 0.20 & 0.20 & 0.25 & 1.20 \\
\hline
\end{tabular}

permitted by the state, yet the amount of income earned from such activity is dependent solely on the laborers themselves and the market. The agricultural cash economy, such as fruit production, may have helped to generate cash income. However, a competitive fruit market has put peasant fruit producers in a very precarious and disadvantageous position.

The peasants' fortune in agricultural production has changed dramatically several times throughout the history of the People's Republic of China (PRC). In the collective period (1950s-1970s), village households suffered severe poverty, but they were protected from the risks of market production. Under the system of "unified purchase and unified sale" of agricultural products, the scale of apple production and sales was arranged by the state on the basis of a planned economy. Since the 1980s, peasant households have experienced not simply a return to household production, but integration into the national market. Peasants working as independent fruit producers, like those in Stone Mill, have to compete with other fruit producers, namely peasants in other provinces, as well as foreign fruit producers who export fruit to China's markets. In the mid-I99os, China's apple production accounted for one-third of the world total, and ninety-five per cent of this was sold on the domestic market. ${ }^{9}$ In the 1990s, the urban markets became saturated as peasant fruit producers began to supply more apples than could be consumed. The price of apples has dropped drastically (see Table I), while the cost of apple production has increased because of the rising prices of insecticide, fertilizer, and production tools, resulting in high overhead investment and low return from fruit sales.

Except for certain labor-intensive tasks (e.g. planting), one $m u$ of corn requires one person to work ten days each year to perform other routine tasks. Thus, for an area of three to four $m u$ of corn for a four-person household, one person needs to work less than forty days a year to farm the household's cornfield. In the case of apple production, one person can usually cultivate Ioo trees of productive age. If a household of four persons (a couple whose young children are not given an allotment of apple trees) is allocated an orchard of fifty such trees, the household needs only one person to work regularly in the orchard. Therefore, for most of the year, a couple with young children will have one extra agricultural laborer.

9. The World Apple Report, January 1998. 
P. Huang has pointed out a feature of Chinese agricultural production during the collective period of the 1950s-1970s, namely growth in productivity without growth in agricultural laborers' income (growth without development). ${ }^{10}$ In Stone Mill today, households may be able to increase fruit production by an intensive investment of labor; however, the income from fruit sales cannot increase accordingly due to the high cost of overhead investment, the risk of market competition, and a surplus of labor. The household is not organized for the ultimate purpose of agricultural production; instead, agricultural production is but a means for family members to survive and to realize life goals, such as marrying off the children, continuing the family line, and earning the family respect and dignity (i.e. mianzi or "face ${ }^{\mathrm{p}}$ ) from kinsmen and neighbors. When income from fruit production became unreliable and when city jobs offered not only a good income but also became socially desirable, Stone Mill villagers began to incorporate wage labor as a vital component of their household economy. This strategy of diversifying the household economy and transferring surplus labor was a characteristic of the traditional Chinese household economy prior to the PRC regime and was simply adapted again by peasants to accomplish both the old and new family goals in the new political-economic regimes of the PRC.

\section{THE ECONOMY AND ORGANIZATION OF PEASANT HOUSEHOLDS}

Owning land used to be the means to survive and thrive. In order to own and expand farmland, peasant families adopted a set of survival strategies to draw resources from local economies or to barter with other peasant families. The traditional household economic strategies included constraining consumption, exporting surplus laborers, and diversifying the household economy. An array of other strategies were also used in order to survive severe poverty or famine; these included child control (e.g. giving children out for adoption), migration (e.g taohuang, i.e. escaping the famine) and begging (yaofan). ${ }^{\text {II }}$ Which survival strategy was used depended on the level of poverty of the family, the harvest that year, and the availability of economic opportunities in the local area. The organization of the Qian family exemplifies the characteristics of the organization of traditional peasant

10. Huang, The Peasant Family and Rural Development, pp. 222-251.

rr. For diversifying household economy and wage labor see Philip C.C. Huang, The Peasant Economy and Social Change in North China (Stanford, CA, 1985); Huang, The Peasant Family and Rural Development, Sidney D. Gamble, North China Villages: Social, Political, and Economic Activities before 1933 (Berkeley, CA, 1963). For child transfer see G. William Skinner, "Family System and Demographic Processes", in David I. Kertzer and Tom Fricke (eds), Anthropological Demography: Toward a New Synthesis (Chicago, IL, 1997), pp. 53-95; Arthur P. Wolf et al., Marriage and Adoption in China, I845-1945 (Stainfet CA tonn) 
households and the cultural economy, which relied on land to secure a subsistence existence and continue the ancestral line. ${ }^{12}$

The Qian couple started their family in the 1880s, and they had six sons and three daughters. The family, which eventually reached four generations, had lived in one household for fifty years working together to expand the family farm. The family had lived a very frugal life and rarely spent money on food or housing. As the family grew, nearly thirty people crowded into the house complex of six bedrooms. Like many other families, the Qians preferred to save money so that they could buy more farmland to produce sufficient food and enable sons to marry.

The division of labor was by gender - men worked for the household's agricultural production contributing to the household's common budget; women worked in the kitchen preparing food for the family and wove after finishing their duty in the common kitchen, the income from which belonged to their conjugal units. When the family had a surplus of labor, the father sent family members to take wage labor jobs. Three sons farmed for a rich household in another village, and two younger grandsons went with their fathers to shepherd pigs and cows for the landlord. The two grown-up grandsons worked on the railway owned by the Japanese, earning 50 yuan a month. In the 1930s and 1940s, a monthly income of 40-50 yuan was very high (as compared with the price of corn at 0.38 yuan $/ \mathrm{kg}$ or 7.5 yuan/dou). However, the family didn't consider working at a railway station as a real and respectable job, for land was considered the peasants' root of life and farming was their bound duty (benfen). The two grandchildren were later called back to work on the farm when the family bought more land.

The Chinese household has been widely recognized for its elasticity in adjusting itself to meet its economic needs. ${ }^{13}$. In the case of the Qian family, male laborers were transferred to other jobs when they had a surplus of farm laborers, and they returned home when the family farm was short of labor. Since the I980s, some rural households have still been able to maintain a large household and profit from a diversification of the household economy or from the expansion of household production. ${ }^{4}$ However, this

12. See James C. Scott, The Moral Economy of the Peasant: Rebellion and Subsistence in Southeast Asia (New Haven, CT, 1976), pp. I-55, for a discussion of the peasant moral economy. Although this paper uses the term "cultural economy", it addresses a similar conception of the traditional peasant economy.

13. See Myron L. Cohen, House United, House Divided: The Chinese Family in Taiwan (New York, 1976); Huang, The Peasant Family and Rural Development, Martin Yang, A Chinese Village: Taitou, Shantung Province (London, 1947).

14. See Barbara Entwistle et al., "Gender and Family Business in Rural China", American Sociological Review, 60 (1995), pp. 36-57; Stevan Harrell, "Geography, Demography, and Family Composition in Three Southwestern Villages", in Davis et al, Chinese Families, pp. 77-102; Mark Selden, "Family Strategies and Structures in Rural North China", in ibid., pp. 139-164. 
has not been the case for many peasant households because the size of households has shrunk since the 1980s. Studies of Chinese peasant families cannot ignore the impact of the intervention by the socialist state. As a result of the implementation of family planning polices, the national average size of rural households had become 4.5 persons with 2.5 adult laborers by the mid-1990s. ${ }^{\text {is }}$ Couples married after the late 1970s have either one child or two children, if the first born is a daughter. State intervention and socialist reforms have seriously weakened the elasticity of rural households as a labor regime. ${ }^{16}$

Since the socialist collectivization of the I950s and with the reduced number of children, peasants no long have the legal option to expand the family farm or the labor elasticity to expand household production. Households have to rely on other strategies to improve their income, which in the case of Stone Mill is urban wage labor. The jobs found in the cities are often temporary or limited to short-term contracts, therefore it has become a common economic strategy to combine agricultural production and wage labor in order to secure the household's survival and to maximize its economic opportunities.

\section{NEW DIVERSIFICATION: URBAN WAGE LABOR AND AGRICULTURAL PRODUCTION}

The traditional cultural economy of self-sufficiency and thrift continues in the village today. Except for holidays or other special occasions, villagers prefer to save money by not buying groceries (e.g. meat, out-of-season vegetables) for daily meals. Subsistence farming secures a baseline supply of food for the family, which is especially indispensable when income from wage labor or fruit cultivation is unstable. Since apple production has become less profitable and more risky, some households have cut down the trees to plant corn; some households continue fruit cultivation, trying their luck in new varieties or other kinds of fruits (e.g. peaches); while other households invest a moderate amount of labor to maintain an orchard, so

15. For China's family planning policies and their implementations see Xizhe Peng, Demographic Transition in China: Fertility Trends since the 1950s (Oxford, 1991). For data on average household size and agricultural laborers see Zhang, Chinese Rural Statistical Annals, 1996, p. 45. For the new custom of early household division, see Myron L. Cohen, "Family Management and Family Division in Contemporary Rural China", China Quarterly, 130 (1992), pp. 357-377; Danyu Wang, "Flying From the Nest: The Household Formation in a Village in Northeastern China" (Ph.D., Brown University, Providence, RI, 1999); Danyu Wang, "Complex Households, a Fading Glory: Household Formation During the Collective Period in the PRC", Journal of Family History, (forthcoming, 2000); Yunxiang Yan, "The Triumph of Conjugality: Structural Transformation of Family Relations in a Chinese Village", Ethnology, 36 (1997), pp. 19I-212.

16. Susan Greenhalgh, "The Peasant Household in the Transition from Socialism: State Intervention and Its Consequences in China", in E. Brumfiel (ed.), The Economic Anthropology of the State (Lanham, MD, 1994), pp. 43-94. 
that they can rely on the orchard when apple production becomes profitable again or when urban wage labor jobs are not available.

Regardless of their differences in fruit production strategies, Stone Mill households are commonly involved in wage labor employment. In the past fifteen years, as rapid regional development and foreign investment in Dalian City has created many job opportunities for people in its rural areas, many Stone Mill households have transferred their laborers to nonagricultural sectors. In 1997, about seventy-three per cent of married men, less than five per cent of married women, and eighty-seven per cent of their unmarried adult children took nonagricultural jobs. Typical jobs taken by Stone Mill villagers include that of carpenter or mason on a construction site or with apartment renovation businesses in the city, contract worker in a factory or service industry, or other temporary physical labor jobs (mao gong).

The arrangement of household economic activities in Stone Mill can be divided into three types depending on where the household places its priority: on fruit production, on wage labor, or on a combination of both. The households of Xiang, Lian, and Neng, demonstrate the three strategies of economy diversification.

In the Xiang family, the parents are in their early thirties, and their two daughters are aged eight and three. In order to take care of their children, the couple has been working primarily in the family orchard since their marriage. While their major source of income is fruit, they also manage to make extra money by taking temporary jobs in the local area, such as spraying insecticide for other households who have primarily engaged in wage labor. The husband also works as a mason on construction sites when the orchard work is light. The couple relies on the orchard for living, while earnings from temporary wage labor supplement the household's income.

In the Lian family, the parents are in their thirties, and the two daughters are seven and twelve years old. The wife, who is considered one of the hardest working and thriftiest women in the village, does most of the housework, farm work, and orchard work. The husband spends most of his time working and living at construction sites as a mason. The couple has done their best to make money from both wage labor and fruit sales.

In the Neng family, the parents are in their late fifties, and there are two unmarried sons and one unmarried daughter. In addition to daily housework, the wife is responsible for major regular tasks in their cornfield of five $m u$, and in their orchard, the size of a five-person allocation, which is over one hundred trees. She works extremely hard to take over the agricultural work so that her husband and the three children can work in factories. Since the market for apples has been worsening, the family decided to maintain only the basic growth of apple trees. The household's income is from the earnings of the husband and of the children at the factory jobs. 
In 1997, thirty per cent of the households in the village were involved primarily in fruit production while expanding their incomes by taking temporary wage labor jobs in their spare time; twenty-five per cent of the households relied primarily on wage labor, while supplementing their income with moderate or below-maintenance-level fruit cultivation; forty-five per cent of the households were involved in both fruit production and wage labor with the husband working mainly at a wage labor job and the wife performing the agricultural tasks in the orchard, with help from the husband in his spare time. All households basically maintained the subsistence production of corn and vegetables, which became the work of the household members who worked at home (usually in agriculture) or other members in their spare time.

\section{THE WITHDRAWAL OF ADULT CHILDREN FROM HOUSEHOLD PRODUCTION}

Households generally try to make the best use of their labor resources (i.e. the couple and their adult children) in either fruit production or wage labor, although not all households can do so successfully. Unmarried adult children enlarge a household's potential labor force; however, the principle of maximizing household labor and income is often compromised by or combined with the strategy of finding city jobs for adult children. Obtaining a city job for children, which is an effective means to survive rural poverty, has been the primary goal of both young people and their parents. In the PRC, rural poverty is not only a problem pertaining to survival, but also one of economic inequality and social hierarchy. The economic inequality between urban and rural societies in the PRC has had a far-reaching impact on the lives of rural people. Compared with urbanites, the peasants of Stone Mill lived in poverty during the collective period (1950s-1970s), as did those in many other rural communities. ${ }^{17}$ Poverty and the frequent scarcity of food in rural areas were much more severe than in urban areas because the state guaranteed the city dwellers employment and a stable food supply, which was called "iron bowls" (tie fanwan) versus the peasant's mud bowls ( $n$ i fanwan). In light of the very low intake of protein products (e.g. eggs, meat) in the collective period, a daily ration of 250-500g corn per person was hardly enough to cover a household's grain consumption. There is no doubt that the return to household farming in the early 1980s has greatly improved agricultural productivity, and that most peasants' households have improved their standard of living as compared with the extreme poverty and even famine that they suffered during the collective period. Stone Mill 
villagers finally have sufficient food to feed the family, but in the meantime urbanites have become wealthier and more modernized. Compared with the affluence of the urban Chinese, the poverty of the peasant Chinese reflects a social inequality that is deeply rooted in the demographic-economic structure of the postsocialist economy of the PRC.

By working in the city, adult children can contribute to improving the income of their parent's household. It is also the hope of the parents that by having nonagricultural jobs in the city (e.g. carpenter, mechanic, chef, or interior renovator), their children may never have to depend on agriculture to make a living. As summarized by a high school teacher in the village, "To be successful (you chuxi) is to study hard and leave rural society (nongcun). It was the case in the collective period, and it is still the same now."

Children, especially sons, are important in the economic and cultural lives of Chinese peasants. They are the embodiment and the means of continuing the family line. In Chinese rural society, individual identity can be said to be a self-centered, patrilineal kinship identity, which is related to one's patrilineal kinship roles as a son/daughter, a grandson/granddaughter and a descendent of one's ancestors. ${ }^{18}$ In rural society, the socioeconomic status of the family is measured by the achievement of the younger generation. Parents place great hopes on their children and make a tremendous effort to support their endeavors. Traditionally, the economic strategy of peasant households, as exemplified in the case of the Qian family, was to keep the household consumption to the minimum level and expand the family farm. With sufficient land, their sons would be able to marry and live decently, the family line could continue, and the parents thus would be able to live up to cultural expectations.

Even though these family goals remain, the means to achieve these goals and the embodiment of them have changed in the postsocialist state. Since there is no private ownership of land, the family farm no longer exists as socioeconomic capital for the family to continue its bloodline. Peasants in the PRC are saddled with low economic status and the negative cultural identity of being considered backward. Being a hardworking peasant no longer necessarily brings sufficient income and social respect. Therefore, the urban employment of peasant children has become not only an opportunity to improve income, but also to enhance social status by having the children marry desirable partners and thereby earn the family respect from the community.

Supporting the urban employment of adult children has a higher priority among the villagers of Stone Mill than the goal of maximizing household income. Adult children who have graduated from high school could replenish labor to household production, especially to those households which are 
able to expand the scale of production. However, nonagricultural employment is overwhelmingly preferred over work in agricultural production (wunong) to the extent that some parents have to limit the scale of household agricultural production. The case of Lanni illustrates the influence of this preference on the organization of household production.

Lanni and her husband are in their mid-forties and have a daughter and a son who have recently graduated from the local junior high school. The daughter has been working in a restaurant as a waitress and as an apprentice to a pastry chef, and the son wants to be a chef as well. Neither of them wants to work in agricultural production of any kind. Lanni's brother, who works in a city, is willing to finance the couple in expanding their orchard or starting a chicken farm. The couple has thought seriously about both plans, but they have finally decided against doing anything because neither the son nor the daughter could leave their city jobs to work for the family.

In order to help their children seek city employment and urban residential status, parents have also paid dearly. A few wealthy families (about fifteen) have bought urban residential status (i.e. a city hukou) ${ }^{19}$ for their young or adult children in the local urban centers at a price of eight thousand yuan, which nearly equals an average household's annual income. A few parents have managed to support their children who passed college entrance qualification examinations. The cost of college tuition and stipend, at 10,000 yuan a year, has not only exhausted the parent's income and savings, but has put the parents in debt. Average families usually help and support their adult children in attaining employment in the competitive job markets of local urban centers. Each year, parents of new graduates make great efforts to find their children a job in nonagricultural sectors. Instead of improving their household income through the urban employment of their children, some parents have invested several thousands of yuan in their children's urban employment.

Those who cannot find nonagricultural employment do not settle for working at the household's agricultural jobs (nonghuo) either. It is not uncommon for these young people to refuse to be fully involved in agricul-

19. The bukou system, which was established in the 1950s, designates people as city or rural inhabitants, according to their status of residence. During the 1950s-1970s, the government exercised strict control over rural-urban migration and urban residential status (i.e. city hukou). One's rural residential status (i.e. a rural hukou), which was based on the rural residential status of one's mother, could hardly be changed. After the I980s, the government began to ease its restrictions in changing residential status. In some areas, there were peasants who could afford to buy a city bukou - at a very high price, however. For more on the Chinese bukou system, see Tiejun Cheng et al., "The Origins and Social Consequences of China's Hukou System", China Quarterly, I39 (1994), Pp. 644-668; Mark Selden, The Political Economy of Chinese Development (Armonk, NJ, 1993) ch. 6; Sulamith Heins Potter, "The Position of Peasants in Modern China's Social Order", Modern China, 9 (1983), pp. 465-499. 
tural jobs at home while their peers are working in the cities - they wait and look for city job opportunities instead. Parents do not count on them as standard full-time laborers in planning the household's agricultural activities, for they also hope that their children will soon find jobs outside the village. Often one sees a jobless young man hanging around in the village in trendy urban clothes, passing his time by playing cards or chatting with people. Some help their parents with agricultural tasks in the orchard or cornfield - however, this help is only temporary. To many young people, wearing the plain peasant garb seems to symbolize the denial of their city dream, to the point that some of them insist on wearing nice clothes even when working in the field. The overt change in farm wear reveals the mindset of the young villagers, who stay at home yet aspire to city jobs.

\section{DECOLLECTIVIZING THE HOUSEHOLD BUDGET}

In rural China, the household $(b u)$ is the basic domestic unit of production, reproduction, and consumption, and is often under the management of the parents, who are also the owners of the household property. The sharing of family property, and often a common budget, is a distinctive feature of Chinese household organization. ${ }^{20}$ It is not essential that a household share a residential unit; various household members can be placed in different houses and at different locations when economic activities need to be carried outside the home community. ${ }^{2 x}$ Unmarried children, regardless of their age, are members of the parents' household until they marry (for daughters) or until the parental wealth is divided up among sons after they marry, whereupon they start their own independent households. In the case of the Qian family in Stone Mill's past, sons and grandsons working and living in another village brought their income back to the household. In today's Stone Mill, adult children commonly take jobs in the local town center, Dalian City, and other places. Those who work in the local area may live at home and commute to work; others live the city where they work and visit home a few times a month or several times a year depending upon the location of the city and the time schedule of the job.

Except for a woman's dowry and private room money (sifangqian), the household traditionally had exclusive ownership of household property and the income of its members. ${ }^{22}$ Household members were supposed to turn all of their income over to the household, leaving the household head to make the consumption and production decisions. Although household

20. For Chinese household organization see Cohen, House United, House Divided; Maurice Freedman, Chinese Lineage and Society: Fukien and Kwangtung (London, 1966).

21. For instance see Cohen, House United, House Divided; Susan Greenhalgh, "Networks and Their Nodes: Urban Society on Taiwan", China Quarterly, 99 (1984), pp. 529-552.

22. See Cohen, House United, House Divided; Rubie S. Watson, 'Women's Property in Republican China: Rights and Practice", Republican China, ro (1984), pp. 1-12. 
members were expected to work their best to contribute to the household, the distribution of household property was based on the egalitarian principle of an equal share per stripe (i.e. each son and his patrilineal branch). ${ }^{23}$ This contradiction between the unequal economic contribution of sons and the equal distribution among sons has created a structural basis for conflict among family members. Family conflict between or among interest groups between generations or among brothers and their wives - has been a major theme of Chinese family life. ${ }^{24}$ It manifests itself in the resistance and rebellion of those children, especially those sons who have contributed to the household more than other siblings yet receive an equal amount of family property when they marry and when the parental property is finally divided up.

In Stone Mill today, thanks to the wage labor jobs first attained in the 1980s, adult children's income from wage labor varies from 100-200 yuan to over I,000 yuan a month. As the discrepancy in economic contribution between siblings increases, so does the dissatisfaction among those who have contributed more than other siblings. Especially those who have not been able to find urban jobs and then wander through the village streets to kill time anger their siblings who have worked hard and contributed significantly to the household's collective budget. In situations like this, parents are willing to support their jobless or low-income children, in the hope that this situation is temporary, but the other children are not pleased about it.

In the case of Fu's three sons, the eldest son had originally given their parents all of his modest earnings from his job as a plumber. His two younger brothers could not find city jobs and stayed at home doing nothing. Their parents encouraged the two younger brothers to keep looking for city jobs and did not ask them to take over the family's farm tasks, which caused the eldest son great dissatisfaction. However, as the two younger brothers began to work in a construction team and interior renovation business, respectively, they brought home income that was several hundreds of yuan more than that of their eldest brother. Foreseeing the discrepancy between their unequal economic contribution and their equal share of the family's payment to their marriages, the two younger brothers were unhappy with the parents' management of their income. Before long, the parents decided to let the sons manage their own income and pay for their own marriages.

As income differences among children has begun to widen, the collective management of a household has become more and more difficult. Beginning

23. See Cohen, House United, House Divided.

24. See ibid.; Maurice Freedman, Lineage Organization in Southeastern China (London, 1958); Maurice, Chinese Lineage and Society; Margery Wolf, Women and Family in Rural Taiwan (Stanford, CA, 1972); Yan, "The Triumph of Conjugality". 
in the 1980s, parents often allowed each son to keep his own income or a portion of his income in order to save on his own for his future marriage. In Stone Mill today, it is common for children to keep at least a portion of their earnings under their own management. (In 1997, only thirty-five per cent of the adult children gave all their wage labor income to their parents; forty per cent kept a portion of their income, and twenty-five per cent kept all the income under their own management for their own consumption and their future marriage.) They often spend this private money on leisure activities in cities, or buying clothes that they would otherwise not be able to buy if all their income was under the control of their parents. They also accumulate their own savings for their future marriages. According to the egalitarian principle of wealth distribution, parents generally spend equal amounts of money on each son's marriage. If a son is able to contribute his own savings to his marriage, then the more he earns, the better equipped his new home will be.

Traditionally, the young couple would not own any conjugal property until after the division of the parental household. Since the I980s, in Stone Mill as in other rural communities, ${ }^{25}$ the conjugal wealth of the young couple at the time of their wedding has increased dramatically to include fixed property (a house) and household facilities (e.g. a television). Contributing to this new conjugal wealth are the groom's parents, the bride's parents, and the bride and groom themselves from their own wage labor income. A large amount of conjugal wealth enhances the economic power and independence of the couple at the time of their marriage. Compared with the collective economy in traditional households, the drastic increase in conjugal wealth is a structural change to the household organization that has economically facilitated the new custom of an early separation of married sons from the parental household, and thus the popularity of nuclear residence. ${ }^{26}$

It is the parents who have sustained the survival of the family and supported the economic improvement of their children, and who have now lost the advantages they had in the traditional household through the transitions taking place in the postsocialist state. With the decollectivization of household budgets, parents have relinquished part of their control over the socioeconomic lives of every family member, and they will hardly improve their chances of regaining it as sons marry, live separately, and manage their 'own financial affairs. Supporting elderly parents has been a Chinese family tradition that continues until today. However, by helping their children leave the village and live in cities or suburban areas, parents have lost the chance to get help from their children on a convenient daily basis. The struggle of these adult peasant children to survive in urban areas has also 
allowed them less time and economic capacity to support their parents. Although some may be able and willing to support their parents, the egalitarian principle, which stipulates that each son contribute equally to parental support, has created additional tension among brothers. If one brother provides more parental support than the others, he will cause dissatisfaction among his siblings, because they will then feel under pressure to pay more themselves. The level and content of parental support, which is often adjusted to the lower-income brothers, is clearly discussed among brothers, who end up specifying in detail the amount of cooking oil, pork, and other life necessities that each son should provide. In the mid-1990s in Stone Mill, forty-one per cent of the couples who had one or both parents alive did not give their parents monetary support. Among those who provided monetary support to their parents, seventy-one per cent gave less than 500 yuan yearly, which equaled five per cent of the average household income. The living standard of elderly parents is much lower than that of their adult children.

\section{FROM A GENDER-BASED TO A COUPLE-BASED DIVISION OF LABOR}

In today's Stone Mill, as in many other rural areas, ${ }^{27}$ agricultural production has become primarily the wife's responsibility, regardless of whether the household engages mainly in wage labor, in both agricultural production and wage labor, or primarily in agricultural production. The traditional inside-outside (nei vs. wai) division of household labor still remains, meaning women work at tasks inside and men outside the home; however, there has been a shift in both the boundaries and content of these categories of inside and outside that has been observed in other rural areas in China as well as in Stone Mill. ${ }^{28}$ In Stone Mill, the inside-outside boundary, which used to be marked by the house, is now marked by the village - women work in the village at agricultural tasks and men take nonagricultural jobs outside of the village. This new boundary is reflected in the way a village woman named Lihua describes her work:

I take care of work inside the home (jiali huo) - housework and tasks in the vegetable garden, the cornfield, and the orchard. My husband and our daughter work in factories in the town. I usually don't let my husband take time off for these inside tasks because he is paid by the hour. My husband takes charge when dealing with matters outside of home (i.e. the outside of the village) (jiawai shi) [...]. For example, he took care of finding jobs for himself and our elder daughter.

27. Martin K. Whyte, "Introduction: Rural Economic Reforms and Chinese Family Patterns (Symposium on Rural Family Change)", China Quarterly, 130 (1992), pp. 317-322.

28. Tamara Jacka, Women's Work in Rural China: Change and Continuity in Era Reform (Cambridge, 1997). 
Husbands, on the other hand, bring home cash from wage labor jobs in addition to their labor in the household production. The husband's contribution to the household income is obvious and often significant. In 1997, among couples married after 1980 (those who are about age forty and younger), fifty per cent of the married men surveyed earned at least half of the household's cash income solely by their wage labor income. By taking wage labor jobs in towns and cities, men have also gained experience in a society beyond the village, and they can establish social contacts with coworkers and others who have access to cities and nonagricultural sectors. These social contacts provide husbands with information and access to wage labor opportunities, and thus to social and economic resources. Thus, husbands are able to secure their male authority as well as the role of "breadwinner" of the family.

As the generational factor comes into play in the analysis of change within the family, one observes an increase in the independence of the younger generation from their parents and their parents-in-law. After they graduate from high school and before they marry and start a household of their own, adult children work in the parental household as additional and somewhat temporary laborers. With the withdrawal of adult children from agricultural production and the prevalence of an early separation from the parental household, the traditional gender division of labor has been reduced to the current conjugal division of labor, centering only on the peasant husband and his wife. Changes in generational relationships in the family have enhanced the traditional gender division of labor on the more immediate conjugal level.

Although traditional gender division still exists, women have been able to extend their arena of activities to a new "inside" sphere, which includes both housework and farm tasks. With this newly expanded domestic sphere, they have begun to improve their participation in decision-making and in the control of household resources. An old saying expresses women's critical role in the traditional household economy: "If you hire incompetent laborers, you will be poor for a year. If you marry an incompetent wife, you will be poor for life" ( $G u$ bu dao hao buoji yi nian shou qiong, qu bu dao hao xifu yibeizi shou qiong). In today's Stone Mill, the wife's ability to utilize her power in distributing household production and consumption resources has grown, and so has the household's dependence on the wife. A married woman makes decisions concerning daily household matters, both at home and on the farm, that were formerly decided by the husband or the parentsin-law in traditional households. Some of these women, especially those with husbands who work principally in wage labor jobs (e.g. Lihua), assume major responsibility in organizing routine agricultural tasks. This expansion of their economic resources has contributed to the young women's independence from the patriarchal authority and control of their parents-in-law, 
and enables them to sustain nuclear households as a new mode of family life.

The universal human need for survival is organized by the household in its own cultural ways under certain socioeconomic conditions. The cultural goal of maintaining family continuity, prosperity, and dignity has remained in contemporary rural China, yet it is pursued with a different set of strategies. The change in the household strategies from the expansion of land to a combination of seeking city jobs for children and improving household income, is the peasants' response to their socioeconomic condition in the postsocialist state. This new set of strategies has not only helped China' peasants to survive the impoverished life, but has also resulted in a reconfiguration of the generational relationships. Despite the prospect of not receiving much in return economically from their adult children while they manage the family household or later in their old age, parents have fully supported the city employment of their adult children, even at the expense of paying for their job searches and training. With the increased income and income differentiation among siblings, the household budget has begun to be decollectivized and the parental power in controlling the household has begun to be decentralized. The traditional mode of parent-centered household management has begun to change. In its place is evolving the rising independence of the younger generation. 